\title{
Editorial
}

Journal of Innate

Immunity

\section{Bacterial Proteases Disarming Host Defense}

This second issue of the Journal of Innate Immunity is in part dedicated to roles of bacterial proteases, counteracting innate immune mechanisms. All bacterial species produce a panel of enzymes, among them proteases, promoting their survival depending on habitat. Interestingly, bacterial proteases are not only involved in housekeeping processes, but also play important roles in neutralizing threats executed by host defense in response to bacterial infestation. The specificity of bacterial proteases is extremely diverse with some proteases having only one substrate while other proteases are able to degrade almost any encountered protein $[1,2]$. In the case of commensal bacteria, a host inflammatory response is rarely elicited and there is a sustained and balanced interaction with the colonized host. On the other hand, pathogenic bacteria possess robust means to neutralize both innate and adaptive immune strategies carried out by the host. As a consequence, more and more proteases from various bacterial species are being considered important virulence factors. Bacterial proteases are in the focus of many research activities and the future will show whether they may become targets for novel treatment strategies of infectious diseases of humans, animals and plants. This is- sue will discuss novel perspectives on bacterial proteases versus innate immunity.

The series of articles will start with an overview of the field written by Potempa and Pike [3] which is followed by an original article by Humann and Lenz [4] providing a view from the bacterial side by discussing to what extent degradation of bacterial cell wall peptidoglycans can protect bacteria from being detected by pathogen recognition receptors. Neutrophils and monocytes are key effector cells in cell-mediated innate immunity and, in the third study, Smagur et al. [5] show how the important human pathogen Staphylococcus aureus can induce cell death by releasing the enzyme staphopain. The next article of this issue's thematic focus is dealing with Porphyromonas gingivalis, an important human pathogen that can cause periodontal disease. Fitzpatrick et al. [6] show that the proteases gingipains of these bacteria induce production of pro-inflammatory cytokines in macrophage-like cells via a nonproteolytic mechanism. Finally, Carlisle et al. [7] show that proteases of Porphyromonas gingivalis are able to degrade the important innate peptide antibiotics, $\alpha$ and $\beta$-defensin, thus avoiding being killed.

Heiko Herwald, Lund; Arne Egesten, Lund

\section{References}

1 von Pawel-Rammingen U, Johansson BP, Björck L: IdeS, a novel streptococcal cysteine proteinase with unique specificity for immunoglobulin G. EMBO J 2002;21:1607-1615.

2 Collin M, Olsén A: Extracellular enzymes with immunomodulating activities: variations on a theme in Streptococcus pyogenes. Infect Immun 2003;71:2983-2992.

3 Potempa J, Pike RN: Corruption of innate immunity by bacterial proteases. J Innate Immun 2009;1:70-87.
4 Humann J, Lenz LL: Bacterial peptidoglycan-degrading enzymes and their impact on host muropeptide detection. J Innate Immun 2009;1:88-97.

5 Smagur J, Guzik K, Magiera L, Bzowska M, Gruca M, Thøgersen IB, Enghild JJ, Potempa J: A new pathway of staphylococcal pathogenesis: apoptosis-like death induced by staphopain B in human neutrophils and monocytes. J Innate Immun 2009;1:98-108
6 Fitzpatrick RE, Aprico A, Wijeyewickrema LC, Pagel CN, Wong DM, Potempa J, Mackie EJ, Pike RN: High molecular weight gingipains from Porphyromonas gingivalis induce cytokine responses from human macrophage-like cells via a nonproteolytic mechanism. J Innate Immun 2009;1:109-117.

7 Carlisle MD, Srikanthab RN, Brogden KA: Degradation of human $\alpha$ - and $\beta$-defensins by culture supernatants of Porphyromonas gingivalis strain 381. J Innate Immun 2009; 1:118-122.

\begin{tabular}{ll}
\hline KARGER & $\begin{array}{l}\text { (c) 2008 S. Karger AG, Basel } \\
\text { 1662-811X/09/0012-0069\$26.00/0 }\end{array}$ \\
$\begin{array}{l}\text { Fax +41 61 306 1234 } \\
\begin{array}{l}\text { E-Mail karger@karger.ch } \\
\text { www.karger.com }\end{array}\end{array}$ & $\begin{array}{l}\text { Accessible online at: } \\
\text { www.karger.com/jin }\end{array}$
\end{tabular}

